\title{
Comparative response of EPO and soluble transferrin receptor at high altitude
}

Citation for published version (APA):

Robach, P., Fulla, Y., Westerterp, K. R., \& Richalet, J. P. (2004). Comparative response of EPO and soluble transferrin receptor at high altitude. Medicine and Science in Sports and Exercise, 36(9), 14931498. https://doi.org/10.1249/01.MSS.0000139889.56481.E0

Document status and date:

Published: 01/01/2004

DOI:

10.1249/01.MSS.0000139889.56481.E0

Document Version:

Publisher's PDF, also known as Version of record

Document license:

Taverne

Please check the document version of this publication:

- A submitted manuscript is the version of the article upon submission and before peer-review. There can be important differences between the submitted version and the official published version of record.

People interested in the research are advised to contact the author for the final version of the publication, or visit the DOI to the publisher's website.

- The final author version and the galley proof are versions of the publication after peer review.

- The final published version features the final layout of the paper including the volume, issue and page numbers.

Link to publication

\footnotetext{
General rights rights.

- You may freely distribute the URL identifying the publication in the public portal. please follow below link for the End User Agreement:

www.umlib.nl/taverne-license

Take down policy

If you believe that this document breaches copyright please contact us at:

repository@maastrichtuniversity.nl

providing details and we will investigate your claim.
}

Copyright and moral rights for the publications made accessible in the public portal are retained by the authors and/or other copyright owners and it is a condition of accessing publications that users recognise and abide by the legal requirements associated with these

- Users may download and print one copy of any publication from the public portal for the purpose of private study or research.

- You may not further distribute the material or use it for any profit-making activity or commercial gain

If the publication is distributed under the terms of Article $25 \mathrm{fa}$ of the Dutch Copyright Act, indicated by the "Taverne" license above, 


\title{
Comparative Response of EPO and Soluble Transferrin Receptor at High Altitude
}

\author{
PAUL ROBACH ${ }^{1,2}$, YVONNE FULLA ${ }^{3}$, KLAAS R. WESTERTERP ${ }^{4}$, and JEAN-PAUL RICHALET ${ }^{1}$ \\ ${ }^{1}$ ARPE, Laboratory "Cellular and Functional Responses to Hypoxia," Faculty of Medicine, Bobigny, FRANCE; ${ }^{2}$ National \\ School for Ski and Mountaineering, Chamonix, FRANCE; ${ }^{3}$ Department of Nuclear Medicine, Cochin Hospital, Paris, \\ FRANCE; and ${ }^{4}$ Department of Human Biology, Maastricht University, Maastricht, THE NETHERLANDS
}

\begin{abstract}
ROBACH, P., Y. FULLA, K. R. WESTERTERP, and J.-P. RICHALET. Comparative Response of EPO and Soluble Transferrin Receptor at High Altitude. Med. Sci. Sports Exerc., Vol. 36, No. 9, pp. 1493-1498, 2004. Purpose: Soluble transferrin receptor (sTfR) classically raises with increased erythropoiesis, along with the rise in erythropoietin (EPO). However, the specific effect of altitude-induced erythropoiesis on STfR remains poorly documented. This study investigated the response of sTfR during high-altitude exposure in human and verified that sTfR was related to EPO response in this case. Methods: EPO, sTfR, red cell volume (RCV), ferritin, and iron intake were measured during: 1) experiment $\mathrm{A}(N=8,31 \mathrm{~d}$ at 5000-8848 m), at sea level (SL), and at the simulated altitude of 5000, 6000, 7000, and $8000 \mathrm{~m}$; and 2) during experiment B (N=10, $7 \mathrm{~d}$ at $4350 \mathrm{~m})$, at SL, after 3, 5, and $7 \mathrm{~d}$ at $4350 \mathrm{~m}$ and 1-2 d after return to SL (RSL). Results: In experiment A, progressive decompression from SL to $8000 \mathrm{~m}$ induced a large parallel rise in EPO (33.8-fold) and STfR (5.9-fold), whereas ferritin was dramatically decreased and iron intake reduced. RCV was increased after $31 \mathrm{~d}$ of decompression. In experiment B, EPO peaked at day 3 at $4350 \mathrm{~m}$, then declined later at altitude and returned to baseline values at RSL, whereas sTfR progressively rose at altitude $(+86 \%)$ and remained elevated during RSL (+64\%). Ferritin progressively declined at $4350 \mathrm{~m}$, whereas iron intake was unchanged. RCV was not enhanced after exposure to $4350 \mathrm{~m}$. Conclusion: In summary, sTfR mirrors EPO response for a given level of altitude hypoxia but differs from EPO response during transitory phases, such as early acclimatization or reoxygenation. Analysis of sTfR may therefore account for altitude-related erythropoiesis, at a time when EPO is blunted. Key Words: HYPOXIA, ACCLIMATIZATION, HEMATOCRIT, HEMOGLOBIN, ERYTHROPOIESIS
\end{abstract}

$\mathrm{E}$ xposure to high altitude enhances erythropoiesis, which promotes a rise in the number of circulating red cells and hemoglobin mass. This process, one of the main features of acclimatization, improves blood $\mathrm{O}_{2}$ carrying capacity in the hypoxic environment. Hypoxiainduced erythropoiesis is triggered by the increased production of erythropoietin (EPO), mainly originating from the kidney (19). In humans, erythropoiesis is basically estimated from serum EPO, which is accepted to be directly related to the rate of renal EPO production.

For a given altitude, serum EPO increases within hours after arrival and reaches a peak on days 1-2 at altitude, then progressively declines to a level close to basal value $(1,8,31)$. Furthermore, the rise in serum EPO is oxygen dependent, i.e., positively related to the degree of hypoxia $(10,16)$. During severe hypoxia, very high stimulation of erythropoiesis may be illustrated by the dramatic increases

\footnotetext{
Address for correspondence: Paul Robach, National School for Ski and Mountaineering, 35 Route du Bouchet, 74401 Chamonix, France; E-mail: paul.robach@ensa.jeunesse-sports.fr.

Submitted for publication March 2004.

Accepted for publication April 2004.
}

0195-9131/04/3609-1493

MEDICINE \& SCIENCE IN SPORTS \& EXERCISE $_{\circledast}$

Copyright (C) 2004 by the American College of Sports Medicine

DOI: 10.1249/01.MSS.0000139889.56481.E0 in serum EPO, previously observed in rats with $7.5 \% \mathrm{O}_{2}(8)$ and in humans at $6542 \mathrm{~m} \mathrm{(21).}$

On the other hand, the changes in erythropoietic activity are associated with alterations in iron metabolism: high erythropoiesis, and subsequent red cell multiplication, implies high iron needs by erythroid progenitors, in order to synthesize heme, whereas the opposite occurs when erythropoiesis is low (5). Therefore, erythropoiesis can be indirectly evaluated through the analysis of iron uptake by the cell, namely by the measurement of the transferrin receptor (TfR), a membrane glycoprotein that regulates cellular uptake of iron from the circulation. A soluble form of TfR (sTfR), identified in human serum and closely related to tissue TfR (17), has made this measure easy to perform and thus, routinely used. The link between STfR and erythropoiesis is evidenced by numerous studies involving patients with erythropoietic disorders, in which sTfR concentration was found closely related to the alterations in serum EPO $(2,14)$.

The question then arises, what is the response of sTfR during high altitude exposure? Literature reveals that data on sTfR during environmental hypoxia remain sparse and mainly concern mild hypoxia $(18,25,28)$. One might suppose that, as for physiopathological situations associated with high erythropoietic responses, sTfR likely reflects the changes in EPO, i.e., increases with altitude-related erythropoiesis. This hypothesis is supported by the fact that the expression of TfR in hypoxia is triggered by the same transcription factor as EPO, namely hypoxia inducible factor (HIF-1) (20). Alternatively, the response of sTfR during 
exposure to high altitude could be different from those of EPO, because sTfR is not only tightly coupled to erythropoiesis, but is also sensitive to mild iron deficiency $(5,27)$, and because a decrease in body iron stores occurs during acclimatization to high altitude, as suggested by the decline in serum ferritin (21).

The aim of the present study was 1) to characterize the alterations in serum sTfR concentration in various altitude conditions and 2) to test the hypothesis that serum sTfR reflects EPO response during high altitude exposure. The practical application of this study was to evaluate to what extent the measure of sTfR, besides EPO and standard hematology, could help to detect a recent high erythropoietic activity, induced either by altitude sojourn or exogenous erythropoiesis stimulation. Serum EPO and sTfR were evaluated in healthy volunteers: A) during a progressive (31 d) decompression in a hypobaric chamber up to the simulated altitude of $8848 \mathrm{~m}$; B) during and after a 1-wk stay at the altitude of $4350 \mathrm{~m}$ in a field laboratory. Experiment A investigates the effect of successive levels of high altitude, increasing by a step-by-step manner (near steady state conditions), whereas experiment $B$ focuses on the acute on- and off-responses during a shorter stay at a given altitude.

\section{METHODS}

\section{Subjects and Procedures}

Experiment A. This experiment was part of Operation Everest III, a simulated ascent of Mt. Everest in a hypobaric chamber at COMEX S.A. in Marseille, France. Complete details of this study have been published previously $(22,23)$. The subjects were eight male volunteers, not acclimatized to high altitude before the experiment. Their mean $( \pm S D)$ age, height, body mass, and sea level $\mathrm{VO}_{2 \max }$ were $27 \pm 4 \mathrm{yr}$, $180 \pm 6 \mathrm{~cm}, 74 \pm 7 \mathrm{~kg}$, and $57 \pm 5 \mathrm{~mL} \cdot \mathrm{min}^{-1} \cdot \mathrm{kg}^{-1}$, respectively. Temperature and hygrometry in the chamber at the time of measurements were controlled between 18 and $24^{\circ} \mathrm{C}$, and 30 and $60 \%$, respectively. The study was approved by the Ethics Committee of the University Hospital of Marseille, France. Subjects were fully informed of all testing procedures and the associated potential risks involved before providing their written consent.

The ascent profile is presented in Figure 1, as described elsewhere $(22,23)$. Subjects were evaluated at sea level and during a 31-d period of decompression, starting from 5000 to $8848 \mathrm{~m}$ (barometric pressure, $\mathrm{P}_{\mathrm{B}}=253 \mathrm{~mm} \mathrm{Hg}$ ). The decompression was preceded by a 6-d preacclimatization in the French Alps, with $1 \mathrm{~d}$ at $3650 \mathrm{~m}$ and $6 \mathrm{~d}$ at $4350 \mathrm{~m}$ (Vallot Observatory), without performing any scientific measurement. For the present study, the measurements were performed at sea level (SL), at the simulated altitude of $5000 \mathrm{~m}\left(\mathrm{P}_{\mathrm{B}}=422 \mathrm{~mm} \mathrm{Hg}\right)$, at $6000 \mathrm{~m}\left(\mathrm{P}_{\mathrm{B}}=370 \mathrm{~mm} \mathrm{Hg}\right)$, at $7000 \mathrm{~m}\left(\mathrm{P}_{\mathrm{B}}=324 \mathrm{~mm} \mathrm{Hg}\right)$, and at $8000 \mathrm{~m}\left(\mathrm{P}_{\mathrm{B}}=284 \mathrm{~mm}\right.$ $\mathrm{Hg}$ ). For each altitude stage, sampling was made in the morning on day 2 (Fig. 1).

Experiment B. This study was performed before, during, and after a 1-wk stay at the Vallot Observatory on

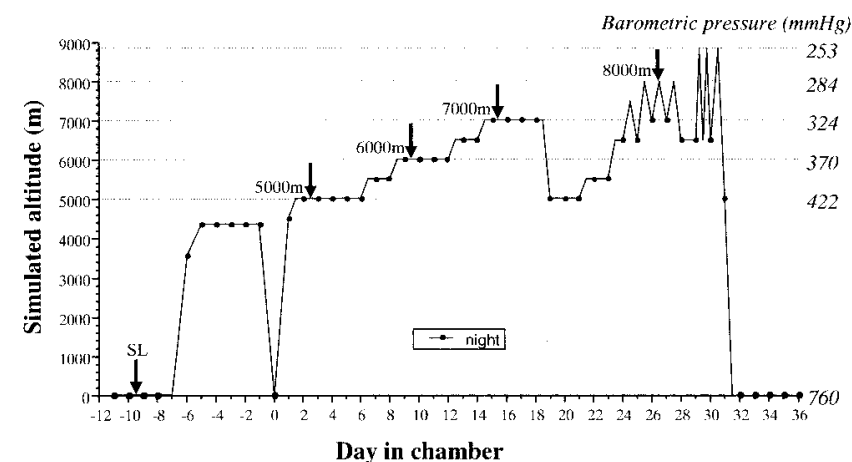

FIGURE 1-Simulated ascent profile of experiment A (Operation Everest III). Arrows indicate days of blood sampling.

Mont-Blanc (altitude $=4350 \mathrm{~m} ; \mathrm{P}_{\mathrm{B}}=448 \mathrm{~mm} \mathrm{Hg}$ ). Complete details of this study are given elsewhere (24). The subjects were 10 male volunteers, not acclimatized to high altitude before the study. Their transportation to- and fromthe high altitude laboratory was done by helicopter. They had a mean ( \pm SD) age of $29 \pm 7 \mathrm{yr}$, height of $175 \pm 4 \mathrm{~cm}$, body weight of $69 \pm 8 \mathrm{~kg}$, and $\mathrm{VO}_{2 \max }$ of $46 \pm 3$ $\mathrm{mL} \cdot \mathrm{min}^{-1} \cdot \mathrm{kg}^{-1}$. Temperature inside the observatory was controlled between 18 and $23^{\circ} \mathrm{C}$. This study was approved by the Ethics Committee of the Necker Hospital, Paris, France. Subjects were fully informed of all testing procedures and the associated potential risks involved before providing their written consent.

The subjects were evaluated at sea level (SL), during the 7-d stay at $4350 \mathrm{~m}$ on the third (H3), fifth (H5), and seventh (H7) days, then $12 \mathrm{~h}$ (RSL1) and $24 \mathrm{~h}$ (RSL2) after return to sea level. During the high altitude sojourn, the level of physical activity remained low. The investigations at sea level, high altitude and RSL2 were performed simultaneously in the morning. For RSL1, all the subjects were evaluated simultaneously on evening at $12 \mathrm{~h}$ postaltitude.

\section{Blood Analyses}

Experiments A and B. All the blood samples were collected by venipuncture from a forearm vein, at rest in a sitting position, after an overnight fast. Blood samples were centrifuged and separated serum stored at $-80^{\circ} \mathrm{C}$ for further analysis. Serum concentration of sTfR was measured by chemoluminescence, using a mouse monoclonal antibody, coupled to biotin and labeled by acridinium ester (Nichols Advantage). The intra- and interassay coefficients of variation for STfR measurement, determined in our laboratory, were $5.6 \%$ and $8.3 \%$, respectively. Serum concentration of EPO was measured by chemoluminescence, using a mouse monoclonal antibody labeled with acridinium ester and a sheep polyclonal antibody labeled with biotin (Nichols Advantage). The intra- and interassay coefficients of variation for EPO measurement, determined in our laboratory, were $5.2 \%$ and $7.1 \%$, respectively. Serum ferritin concentration was measured using an immunoradiometric assay (RIAgnost Ferritin, Behring, Marburg, Germany). The intra- and interassay coefficients of variation for ferritin measurement, 
TABLE 1. Venous hemoglobin concentration ([Hb]) and venous hematocrit ( $\mathrm{Hct}) 1$ ) at sea level (SL) and during progressive simulated exposure to $8848 \mathrm{~m}$ (experiment $A$ ); and 2) before (SL), during a 1-wk exposure to $4350 \mathrm{~m}$ and after return to sea level (RSL1: $12 \mathrm{~h}$; RSL2: $24 \mathrm{~h}$ ) (experiment B).

\begin{tabular}{|c|c|c|c|c|c|}
\hline & \multicolumn{5}{|c|}{ Experiment A } \\
\hline & SL & $5000 \mathrm{~m}$ & $6000 \mathrm{~m}$ & $7000 \mathrm{~m}$ & $8000 \mathrm{~m}$ \\
\hline \multirow{4}{*}{$\begin{array}{l}{[\mathrm{Hb}]\left(\mathrm{g} \cdot \mathrm{dL}^{-1}\right)} \\
\operatorname{Hct}(\%)\end{array}$} & $14.8 \pm 1.4$ & $16.4 \pm 1.2^{*}$ & $16.8 \pm 1.0^{*}$ & $16.7 \pm 1.3^{*}$ & $18.4 \pm 1.5^{\star}$ \\
\hline & $46.3 \pm 3.0$ & $52.0 \pm 3.3^{\star}$ & $53.3 \pm 2.9^{\star}$ & $55.6 \pm 2.9^{*}$ & $56.6 \pm 5.0^{*}$ \\
\hline & \multicolumn{5}{|c|}{ Experiment B } \\
\hline & SL & \multicolumn{2}{|r|}{$4350 \mathrm{~m}$} & RSL1 & RSL2 \\
\hline$[\mathrm{Hb}]\left(\mathrm{g} \cdot \mathrm{dL}^{-1}\right)$ & \multirow{2}{*}{$\begin{array}{l}14.9 \pm 0.8 \\
44.0 \pm 2.6\end{array}$} & \multirow{2}{*}{\multicolumn{2}{|c|}{$\begin{array}{l}16.8 \pm 1.2^{*} \\
48.5 \pm 3.1^{*}\end{array}$}} & \multirow{2}{*}{$\begin{array}{l}16.3 \pm 1.0^{*} \\
47.7 \pm 3.2^{*}\end{array}$} & $15.4 \pm 1.0^{\star}$ \\
\hline Hct $(\%)$ & & & & & $44.7 \pm 3.1$ \\
\hline
\end{tabular}

Values are means $\pm S D$ : Experiment A: $N=8$, except for $8000 \mathrm{~m}(N=7)$. Experiment B: $N=10$, blood samples for [Hb] and Hct were obtained on day 7 at $4350 \mathrm{~m}$. For both experiments: * $P<0.05$ vs sea level.

determined in our laboratory, were $1.9 \%$ and $5.7 \%$, respectively. Hemoglobin concentration $([\mathrm{Hb}])$ was measured by spectrophotometry (CO-oximeter, model 270, Bayer Diagnostics) and the hematocrit by microcentrifugation.

\section{Iron Intake}

Experiments A and B. Iron intake from food and beverages was measured daily in a dietary record during the whole experiment. The subjects recorded intake during each meal and snack, using table scales to weigh individual food items and a graduate container for volume of drinks. Food tables (7) were used to determine daily iron intake. Sea level values were averaged from data obtained during four (experiment A) and three (experiment B) consecutive days; altitude values in experiment $A$ were averaged from data obtained during the first $2 \mathrm{~d}$ at each altitude stage.

\section{Red Cell Volume Measurement}

The respective methods and results on intravascular fluid compartments have been previously described in details for experiment A (23) and for experiment B (24). In experiment $\mathrm{A}$, red cell volume was determined by Evans blue dilution (T-1824): the data mentioned in the present report are those obtained at sea level, before, and 1-3 d after the end of hypobaric exposure. In experiment $\mathrm{B}$, red cell volume was measured by a carbon monoxide rebreathing technique: the data mentioned in the present report are those obtained at sea level, before, and $2 \mathrm{~d}$ after the end of the altitude sojourn.

\section{Statistics}

Experiments A and B. Data are presented as arithmetic mean \pm SD. Because EPO, sTfR, and ferritin values are not normally distributed, median and 25th and 75th percentiles are also shown for these parameters. A one-way ANOVA with repeated measures was used to compare the effect of altitude and return to sea level. A Student Newman-Keuls test was used for multiple comparisons. A Pearson product-moment correlation test was used to analyze the relationship between two quantitative variables. Differences were considered significant at $P<0.05$.

\section{RESULTS}

Experiment $\mathbf{A}$. $[\mathrm{Hb}]$ and hematocrit progressively increased as simulated altitude was raised (Table 1). Serum EPO progressively increased as decompression was raised (Fig. 2A). A 33.8-fold increase in mean EPO occurred from sea level $\left(18.8 \pm 4.6 \mathrm{U} \cdot \mathrm{L}^{-1}\right)$ to $8000 \mathrm{~m}(653.8 \pm 513.7$ $\left.\mathrm{U} \cdot \mathrm{L}^{-1}\right)$. Serum sTfR followed a similar time course, being increased from $17.5 \pm 4.2 \mathrm{nmol} \cdot \mathrm{L}^{-1}$ before decompression to $121.4 \pm 54.8 \mathrm{nmol} \cdot \mathrm{L}^{-1}$ at the simulated altitude of $8000 \mathrm{~m}$ (Fig. 2A). Serum ferritin, sharply decreased with hypobaric exposure, reaching very low values at $8000 \mathrm{~m}$
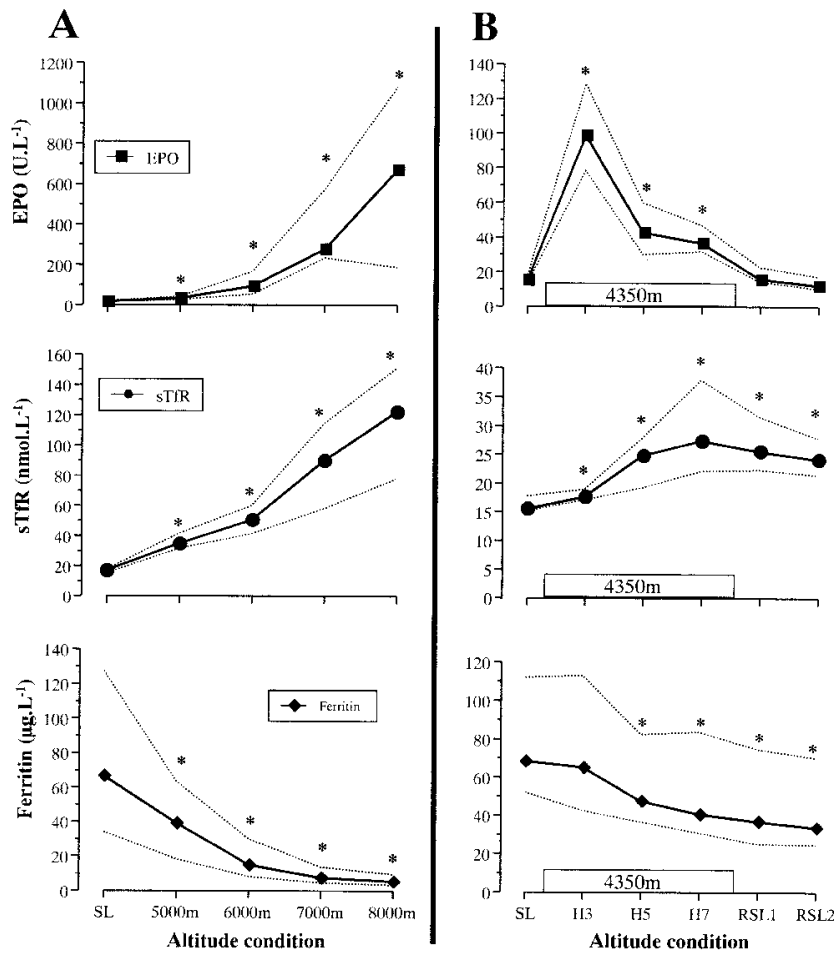

FIGURE 2-Variations in serum erythropoietin (EPO), soluble transferrin receptor (sTfR), and ferritin (A) at sea level (SL) and during a 31-d progressive decompression (experiment $\mathrm{A}: N=8$, except for $8000 \mathrm{~m}$, where $N=7$ ); and (B) at SL and during and after a 7-d sojourn at $4350 \mathrm{~m}$ (experiment $\mathrm{B}: N=10, \mathrm{H3}, \mathrm{H5}$, and $\mathrm{H7}$ are third, fifth, and seventh days after arrival at $4350 \mathrm{~m}$, respectively; RSL1 and RSL2 are $12 \mathrm{~h}$ and $24 \mathrm{~h}$ after return to sea level, respectively). Values are median and 25 th and 75 th percentiles. The ordinate ranges for EPO, sTfR, and ferritin are different between $A$ and B. $* P<0.05$ altitude or return to sea level vs sea level. 

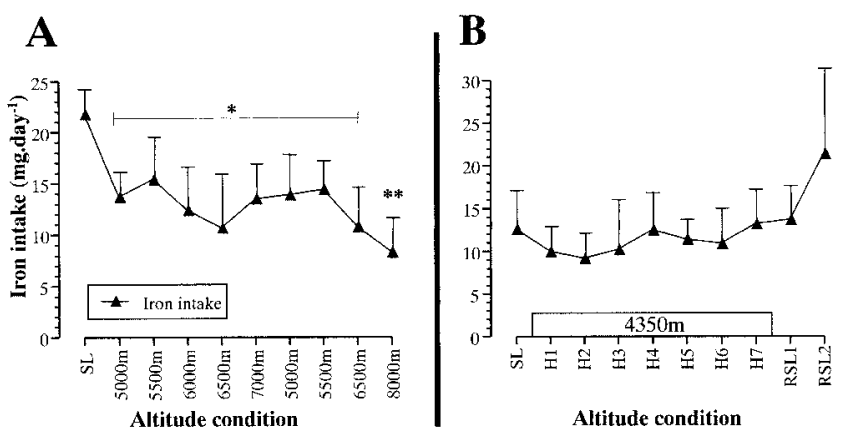

FIGURE 3-Variations in daily iron intake A) at sea level (SL) and during a 31-d progressive decompression (experiment A: $N=8$, except for $8000 \mathrm{~m}$, where $N=7$ ); and $\mathrm{B}$ ) at SL and during and after a 7-d sojourn at $4350 \mathrm{~m}$ (experiment $\mathrm{B}: N=10, \mathrm{H1}$ to $\mathrm{H} 7$ are first to seventh days after arrival at $4350 \mathrm{~m}$, respectively; RSL1 and RSL2 are $12 \mathrm{~h}$ and $24 \mathrm{~h}$ after return to sea level, respectively). Values are mean $\pm \mathrm{SD}$; $* P<0.05$ altitude vs sea level; $* * P<0.058000 \mathrm{~m}$ vs other altitude stages.

$\left(6.5 \pm 4.1 \mu \mathrm{g} \cdot \mathrm{L}^{-1}\right)$ (Fig. 2A). The subjects experienced an initial decrease in total iron intake as decompression started (Fig. 3A). Iron intake then remained stable with altitude gain but decreased further at $8000 \mathrm{~m}$. Red cell volume was significantly increased by the hypobaric exposure, from $2.52 \pm 0.43 \mathrm{~L}$ at sea level before decompression, to $3.24 \pm$ $0.80 \mathrm{~L}(P<0.05) 1-3 \mathrm{~d}$ after return to sea level (23). Finally, individual sTfR data were correlated to the corresponding EPO data $(N=39)$ : $[\mathrm{sTfR}]=33.298+0.116 \times$ [EPO]; $\mathrm{R}^{2}=0.83 ; P<0.0001$.

Experiment B. $[\mathrm{Hb}]$ and hematocrit rose significantly at high altitude but had almost returned to initial values on day 2 after return to sea level (Table 1). Serum EPO significantly increased during high-altitude exposure (Fig. 2B). EPO reached a peak on day 3 at $4350 \mathrm{~m}$, then declined to lower values, still above prealtitude levels. EPO had returned to basal values $12 \mathrm{~h}$ after descent from $4350 \mathrm{~m}$. In contrast, serum sTfR progressively increased at high altitude, reaching a peak after $7 \mathrm{~d}$ at $4350 \mathrm{~m}$ (Fig. 2B). During the first $2 \mathrm{~d}$ of return to sea level, sTfR remained elevated above basal values. Serum ferritin progressively decreased at high altitude, and this decrement was not reversed during early return to sea level (Fig. 2B). Iron intake was not altered by $1 \mathrm{wk}$ spent at $4350 \mathrm{~m}$ (Fig. 3B). Finally, this 1-wk stay at $4350 \mathrm{~m}$ did not induce any increase in red cell volume, mean values being $2.34 \pm 0.11 \mathrm{~L}$ at sea level before altitude exposure, and $2.29 \pm 0.26 \mathrm{~L}$ on day 2 after return to sea level (24). Finally, individual sTfR data were not correlated to the corresponding EPO data $(N=60)$ : [sTfR] $=26.102-0.032 \times[\mathrm{EPO}] ; \mathrm{R}^{2}=0.01 ; P=0.39$.

\section{DISCUSSION}

The main finding of the present study was that sTfR globally reflected EPO response for a given level of environmental hypoxia but was disconnected from EPO changes during transitory phases, such as early acclimatization and return to sea level. Thus, although our results confirm in hypobaric hypoxia what has been previously shown from various erythropoietic disorders, that is, that the rise in sTfR was strongly dependent on enhanced erythropoiesis, they also suggest that the control of sTfR production may differ from those of EPO during hypoxia-induced erythropoiesis.

EPO response. Our data on serum EPO time course at $4350 \mathrm{~m}$ are in agreement with numerous previous works $(1,8,13,31)$ showing that, for a given altitude, serum EPO increased during the first days, then progressively declined, in spite of the persistence of the renal hypoxic stimulus. The reason why serum EPO follows a biphasic response at altitude still remains unclear. It was previously suggested that such changes may reflect the transient imbalance between 1) an early and permanently high renal EPO production and 2) a delayed rise in EPO consumption (12). Indeed, studies from anemic patients with low or high erythroid activity strongly suggest that serum EPO is regulated both by the rate of renal production and by the rate of utilization by erythroid cells (6). On the other hand, data from molecular biology may also account for EPO pattern at high altitude, because the expression of HIF-1 itself, which is known to play a key role on EPO gene activation (15), rapidly increases, then progressively declines in hypoxia (29).

To our knowledge, the measurement of serum EPO in experiment $\mathrm{A}$ is the only one obtained in human up to the simulated altitude of $8000 \mathrm{~m}$, corresponding to a mean arterial $\mathrm{PO}_{2}$ of $37 \mathrm{~mm} \mathrm{Hg}$ and a mean arterial $\mathrm{O}_{2}$ saturation of $68 \%$ (22). However, the magnitude of EPO increase at $8000 \mathrm{~m}$ (34-fold) was not higher than the 37-fold increase in serum EPO previously collected in field conditions at $6542 \mathrm{~m}$ (21) and much lower that the rise in serum EPO observed in rats acutely exposed to $7.5 \% \mathrm{O}_{2}(\approx 8000 \mathrm{~m})(8)$. Thus, EPO values measured at $8000 \mathrm{~m}$ in experiment A, although very high, probably did not reflect the potential maximal increase in serum EPO with this level of hypoxia, because the subjects reached $8000 \mathrm{~m}$ after having been exposed to progressive hypobaria for $4 \mathrm{wk}$.

sTfR response. Previous reports on sTfR response during ambient hypoxia are few and mainly concern intermittent exposure to mild hypoxia $(2500-3500 \mathrm{~m})$ in athletes: in these works, sTfR was found slightly increased after 1-3 wk of intermittent hypoxia $(18,25,28)$. Conversely, sTfR was not found higher during a 10-d sojourn at $3600 \mathrm{~m}$ in untrained subjects (13). Finally, two investigations demonstrated that people living at $1600 \mathrm{~m}$ (3) or 3000-4300 m (4) experienced a significant increase in sTfR. In the present study, first, the sixfold increase in sTfR observed at $8000 \mathrm{~m}$ suggests that a very high TfR expression can be elicited in healthy human during severe hypoxia. The magnitude of this increase may be compared with the 9.6-fold rise in STfR found in $\beta$-thalassemia patients, who experience the highest range of sTfR levels (5). Second, serial measurements of sTfR at $4350 \mathrm{~m}$ demonstrate a specific time course, different from EPO response; particularly, sTfR remains elevated at a time when EPO is blunted (1 wk of acclimatization) or suppressed (return to sea level).

From the present data, the question arises, what are the controlling factors of sTfR response during high altitude 
exposure? The first determinant of sTfR production is the rate of erythropoiesis, as supported by studies from pathophysiology $(2,14)$. This is confirmed in healthy subjects in experiment A by the close relationship found between sTfR and EPO during gradual decompression. Two factors may account for this relationship: 1) HIF-1, which upregulates both EPO (15) and sTfR (20) expressions during hypoxia; and 2) EPO, which can directly act on TfR expression (26).

The second determinant of sTfR production is iron availability: iron deficiency raises sTfR, whereas the opposite occurs when iron stores are high (5). In the present study, we estimated the level of iron stores through serum ferritin. During prolonged high altitude exposure, serum ferritin classically decreases (21), because of the high iron needs for hemoglobin synthesis. Furthermore, ferritin expression may be down-regulated by hypoxia (30). Nevertheless, the present data showed that prolonged exposure to severe hypoxia induced a dramatic drop (92\%) in ferritin level (mean of $6.5 \mu \mathrm{g} \cdot \mathrm{L}^{-1}$ at $8000 \mathrm{~m}$ ), which was under the cut-off of 15 $\mu \mathrm{g} \cdot \mathrm{L}^{-1}$, indicating absent iron stores in humans (11). Undoubtedly, besides high erythropoiesis, the depleted iron stores in our subjects contributed to the large rise in sTfR during gradual decompression. Such a depletion in iron stores (low ferritin and high sTfR) has to be related to the likely dramatic change in iron distribution from circulating iron to hemoglobin, because the $720-\mathrm{mL}$ increase in red cell mass experienced by our subjects at simulated altitude, caused mobilization of about $700 \mathrm{mg}$ of storage iron. Finally, we cannot exclude that the decrease in iron intake (see Fig. 3A), related to an overall decrease in food intake due to altitude-induced anorexia, may have contributed to lower ferritin (32).

In the present study, we also showed that sTfR was not related to EPO response during transitory phases, i.e., early acclimatization and return to sea level. Our result may be compared to a previous report, indicating that athletes who received recombinant human EPO experienced an early and total blunting of EPO after treatment, whereas sTfR remained elevated for as long as $2 \mathrm{wk}$ after treatment (4). The dissociation we observed in the present study could be

\section{REFERENCES}

1. Abbrecht, P. H., and J. K. Little. Plasma erythropoietin in men and mice during acclimatization to different altitudes. J. Appl. Physiol. 32:54-58, 1972.

2. Ahn, J., and R. M. Johnstone. Origin of a soluble truncated transferrin receptor. Blood 81:2442-2451, 1993.

3. Allen, J., K. R. Backstrom, J. A. Cooper, et al. Measurement of soluble transferrin receptor in serum of healthy adults. Clin. Chem. 44:35-39, 1998.

4. Audran, M., R. Gareau, S. Matecki, et al. Effects of erythropoietin administration in training athletes and possible indirect detection in doping control. Med. Sci. Sports Exerc. 31:639-645, 1999.

5. Beguin, Y. The soluble transferrin receptor: biological aspects and clinical usefulness as quantitative measure of erythropoiesis. Haematologica 77:1-10, 1992.

6. Cazzola, M., R. Guarnone, P. Cerani, E. Centenara, A. Rovati, and Y. BEGUIN. Red blood cell precursor mass as an independent explained, at least in part, by the different half-life of both substances. EPO half-life in the circulation is very short (2 h) (9), whereas sTfR half-life seems to be long (estimated from some animal studies), even if, to our knowledge, it has not been measured yet (Beguin, personal communication). In this scheme, the progressive increase in sTfR over $1 \mathrm{wk}$ at $4350 \mathrm{~m}$ would reflect the persistence of a high erythropoietic activity over time at high altitude, which may not be demonstrated from EPO data. Furthermore, high sTfR during early return to sea level may account for a still supranormal erythropoietic activity, at a time when EPO increase was totally suppressed. Thus, even if both sTfR and EPO assess erythropoiesis, the rate of production and/or degradation of each molecule would be controlled differently. Finally, with respect to iron availability, the response of sTfR during and after exposure to $4350 \mathrm{~m}$ was unlikely related to iron deficiency, as suggested by the modest decrement in ferritin throughout the study (lowest mean value $\left.=45.2 \mu \mathrm{g} \cdot \mathrm{L}^{-1}\right)$.

In summary, we showed that sTfR globally reflected EPO response for increasing levels of hypoxia but was disconnected from EPO changes during transitory phases, such as early acclimatization and return to sea level. The present results suggest that sTfR may be used as an index of altitude-related erythropoiesis, when EPO response is blunted. In practice, the detection of a recent high erythropoietic activity (altitude sojourn or exogenous erythropoiesis stimulation) may be achieved through the measurement of sTfR, at a time when EPO, hematocrit, hemoglobin, or red cell volume is not different from baseline.

We thank the administrative and technical crews of COMEX S.A. for assistance provided to the investigators and the eight subjects during experiment $A$. The authors also thank the 10 volunteers of experiment B, as well as the Bayer Diagnostics company, for its participation to both experiments. We thank Dr. Jean-Pierre Herry, Ecole Nationale de Ski et d'Alpinisme, for his skillful assistance during the high-altitude experiments and the Laboratoire de Glaciologie et Géophysique de l'Environnement (CNRS) for the use of the Vallot facilities.

This study was made possible by grants from the Région Provence Alpes Côte d'Azur and Ministère des Sports.

determinant of serum erythropoietin level. Blood 91:2139-2145, 1998.

7. Dutch Nutrient Data Base, 1993. The Hague, The Netherlands, 1993.

8. Eckardt, K. U., J. Dittmer, R. Neumann, C. Bauer, and A. Kurtz. Decline of erythropoietin formation at continuous hypoxia is not due to feedback inhibition. Am. J. Physiol. 258:F1432-F1437, 1990.

9. Embury, S. H., J. F. Garcia, N. Mohandas, R. Pennathur-Das, and M. R. Clark. Effects of oxygen inhalation on endogenous erythropoietin kinetics, erythropoiesis, and properties of blood cells in sickle-cell anemia. N. Engl. J. Med. 311:291-295, 1984.

10. Ge, R. L., S. Witкowski, Y. Zhang, et al. Determinants of erythropoietin release in response to short-term hypobaric hypoxia. J. Appl. Physiol. 92:2361-2367, 2002.

11. Goodnough, L. T., B. Skikne, and C. Brugnara. Erythropoietin, iron, and erythropoiesis. Blood 96:823-833, 2000. 
12. Grover, R. F., and P. BäRTSCH. Blood. In: High Altitude: An Exploration of Human Adaptation, T. F. Hornbein and R. B. Schoene (Eds.). New York: Marcel Dekker, Inc., 2001, pp. 493-523.

13. Gunga, H. C., L. Rocker, C. Behn, et al. Shift working in the Chilean Andes $(>3,600 \mathrm{~m})$ and its influence on erythropoietin and the low-pressure system. J. Appl. Physiol. 81:846-852, 1996.

14. Huebers, H. A., Y. Beguin, P. Pootrakul, D. Einspahr, and C. A. FinCH. Intact transferrin receptors in human plasma and their relation to erythropoiesis. Blood 75:102-107, 1990.

15. Jiang, B. H., E. Rue, G. L. Wang, R. Roe, and G. L. Semenza. Dimerization, DNA binding, and transactivation properties of hypoxia-inducible factor 1. J. Biol. Chem. 271:17771-17778, 1996.

16. Klausen, T. The feed-back regulation of erythropoietin production in healthy humans. Dan. Med. Bull. 45:345-353, 1998.

17. Kohgo, Y., Y. NiItsu, H. Kondo, et al. Serum transferrin receptor as a new index of erythropoiesis. Blood 70:1955-1958, 1987.

18. Koistinen, P. O., H. Rusko, K. Irjala, et al. EPO, red cells, and serum transferrin receptor in continuous and intermittent hypoxia. Med. Sci. Sports Exerc. 32:800-804, 2000.

19. Lacombe, C., J. L. Da Silva, P. Bruneval, et al. Peritubular cells are the site of erythropoietin synthesis in the murine hypoxic kidney. J. Clin. Invest. 81:620-623, 1988.

20. LoK, C. N., and P. PonKa. Identification of a hypoxia response element in the transferrin receptor gene. J. Biol. Chem. 274: 24147-24152, 1999.

21. Richalet, J.-P., J.-C. Souberbielle, A.-M. Antezana, et al. Control of erythropoiesis in humans during prolonged exposure to the altitude of 6,542 m. Am. J. Physiol. 266:R756-R764, 1994.

22. Richalet, J.-P., P. Robach, S. Jarrot, et al. Operation Everest III (COMEX '97). Effects of prolonged and progressive hypoxia on humans during a simulated ascent to $8,848 \mathrm{~m}$ in a hypobaric chamber. Adv. Exp. Med. Biol. 474:297-317, 1999.

23. Robach, P., M. Dechaux, S. Jarrot, et al. Operation Everest III: role of plasma volume expansion on $\dot{\mathrm{V}}_{2}$ max during prolonged high-altitude exposure. J. Appl. Physiol. 89:29-37, 2000.
24. Robach, P., E. Lafforgue, N. V. Olsen, et al. Recovery of plasma volume after 1 week of exposure at 4,350 m. Pflügers Arch. 444:821-828, 2002.

25. Robach, P., L. Schmitt, J. Brugniaux, et al. Living high-training low: effect on erythropoiesis and aerobic performance in highly trained cross-country skiers (Abstract). High Alt. Med. Biol. 3:430, 2002.

26. Sawyer, S. T., and S. B. Krantz. Transferrin receptor number, synthesis, and endocytosis during erythropoietin-induced maturation of Friend virus-infected erythroid cells. J. Biol. Chem. 261: 9187-9195, 1986.

27. Skikne, B. S., C. H. Flowers, and J. D. Cook. Serum transferrin receptor: a quantitative measure of tissue iron deficiency. Blood 75:1870-1876, 1990.

28. Stray-Gundersen, J., R. F. Chapman, and B. D. Levine. "Living high-training low" altitude training improves sea level performance in male and female elite runners. J. Appl. Physiol. 91:11131120, 2001.

29. Stroka, D. M., T. Burkhardt, I. Desbaillets, et al. HiF-1 is expressed in normoxic tissue and displays an organ-specific regulation under systemic hypoxia. FASEB J. 15:2445-2453, 2001.

30. Toth, I., L.Yuan, J. T. Rogers, H. Boyce, and K. R. Bridges. Hypoxia alters iron-regulatory protein-1 binding capacity and modulates cellular iron homeostasis in human hepatoma and erythroleukemia cells. J. Biol. Chem. 274:4467-4473, 1999.

31. Weil, J. V., G. Jamieson, D. W. Brown, and R. F. Grover. The red cell mass-arterial oxygen relationship in normal man. Application to patients with chronic obstructive airway disease. J. Clin. Invest. 47:1627-1639, 1968.

32. Westerterp, K. R., E. P. Meijer, M. Rubbens, P. Robach, and J.-P. RichalET. Operation Everest III: energy and water balance. Pflügers Arch. 439:483-488, 2000. 